\title{
Evaluasi Pembelajaran: Kemampuan Koneksi Matematis Siswa SMPN 1 dan SMPN 2 Kepenuhan
}

\author{
Hera Deswita ${ }^{1}$, Marfi Ario ${ }^{2}$ \\ Pendidikan Matematika, Universitas Pasir Pengaraian ${ }^{12}$ \\ Email: heraiwit18@gmail.com ${ }^{1}$, marfi.ario.92@gmail.com ${ }^{2}$
}

\begin{abstract}
ABSTRAK: Kajian mengenai profil kemampuan koneksi matematis penting untuk dilakukan sebagai langkah awal untuk melakukan evaluasi demi memperbaiki kualitas kemampuan siswa. Ketidakpahaman siswa pada suatu konsep akan mempengaruhi pemahaman siswa pada konsep yang lain. Oleh karenanya, penelitian ini bertujuan untuk melakukan evaluasi pembelajaran dalam kaitannya dengan kemampuan koneksi matematis siswa. Penelitian ini merupakan penelitian kuantitatif deskriptif yang bertujuan untuk mendeskripsikan profil kemampuan koneksi matematis siswa dalam menyelesaikan permasalahan matematis. Objek penelitian adalah siswa SMPN 1 dan SMPN 2 Kepenuhan tahun pelajaran 2017/2018 dengan jumlah siswa masing-masing 17 dan 24 siswa. Pengumpulan data melalui pemberian tes koneksi matematis. Analisis data dengan menghitung persentase nilai siswa pada setiap indikator kemampuan koneksi matematis. Hasil penelitian menunjukkan bahwa kemampuan koneksi matematis siswa SMPN 1 dan SMPN 2 Kepenuhan sangat rendah dengan rata-rata masing-masing 40,52 dan 7,41. Indikator kemampuan koneksi matematis yang paling sulit bagi siswa SMPN 1 Kepenuhan adalah menghubungkan antara matematika dan kehidupan sehari-hari. Sedangkan indikator kemampuan koneksi matematis yang paling sulit bagi siswa SMPN 2 Kepenuhan adalah menghubungkan berbagai konsep dalam matematika.
\end{abstract}

Kata Kunci : Profil, Kemampuan, Koneksi Matematis

ABSTRACT: The study of the mathematical connection ability profile is important as a first step in conducting an evaluation in order to improve the quality of students' abilities. Students 'lack of understanding of a concept will affect students' understanding of other concepts. Therefore, this study aims to evaluate learning in relation to students' mathematical connection abilities. This research is a descriptive quantitative research which aims to describe the profile of students' mathematical connection ability in solving mathematical problems. The research objects were students of SMPN 1 and SMPN 2 Kepenuhan at the 2017/2018 school year with 17 and 24 students, respectively. Data collection through giving mathematical connection tests. Data analysis by calculating the percentage of student scores on each indicator of mathematical connection ability. The results showed that the mathematical connection ability of the students of SMPN 1 and SMPN 2 Kepenuhan was very low with an average of 40.52 and 7.41, respectively. The most difficult indicator of mathematical connection ability for students of SMPN 1 Kepenuhan is the connection between mathematics and everyday life. Meanwhile, the most difficult indicator of mathematical connection ability for students of SMPN 2 Kepenuhan is to connect various concepts in mathematics.

Keywords: Profile, Ability, Mathematical Connection 


\section{PENDAHULUAN}

Pembelajaran matematika merupakan suatu proses belajar atau proses interaksi antara guru dan siswa dan sumber belajar yang melibatkan pengembangan pola berpikir siswa dalam pemecahan masalah matematis yang ada dan siswa diharapkan juga mampu untuk mengaplikasikannya dalam kehidupan sehari-hari. Pembelajaran matematika adalah upaya untuk membantu siswa untuk mengkonstruksi konsep-konsep atau prinsip-prinsip matematika dengan kemampuannya sendiri. Berkaitan dengan hal itu salah satu tujuan pembelajaran matematika untuk satuan pendidikan dasar dan menengah menurut Depdiknas (2006:140) bahwa mata pelajaran matematika bertujuan agar siswa memiliki kemampuan memahami konsep matematika, menjelaskan keterkaitan antarkonsep dan mengaplikasikan konsep atau algoritma, secara luwes, akurat, efisien, dan tepat, dalam pemecahan masalah.

Materi dalam pembelajaran matematika merupakan prasyarat bagi materi lainnya, atau konsep yang satu diperlukan untuk menjelaskan konsep yang lainnya. Sebagai ilmu yang saling berkaitan, siswa diharapkan memiliki kemampuan untuk saling menghubungkan materi-materi yang telah mereka terima untuk memecahkan persoalan-persoalan matematika yang memiliki keterkaitan baik terhadap materi yang dipelajari sebelumnya, maupun dalam kehidupan sehari-hari. Kemampuan ini disebut dengan kemampuan koneksi matematis. Koneksi matematis dapat pula diartikan sebagai keterkaitan antara konsep-konsep matematika secara internal yaitu berhubungan dengan matematika itu sendiri ataupun keterkaitan secara eksternal, yaitu matematika dengan bidang lain baik bidang studi lain maupun dengan kehidupan sehari-hari.

$$
\text { Menurut Sugiman }
$$

kemampuan koneksi matematis merupakan hal yang penting namun siswa yang menguasai konsep matematika tidak dengan sendirinya pintar dalam mengoneksikan matematika.

Menurut NCTM (2000) koneksi matematis bukanlah sebagai kumpulan yang terpisah. Sebaliknya matematika adalah bidang studi yang terpadu. Ketika siswa menghubungkan ide-ide matematika, pemahaman mereka lebih dalam dan lebih lama dan matematika itu sendiri sebagai kesatuan yang utuh. Koneksi matematika dalam pembelajaran dari pra TK hingga kelas 12 harus memungkinkan siswa untuk memiliki 1) Aspek koneksi antar topik matematika, 2) Aspek koneksi dengan ilmu lain, 3) Aspek koneksi dengan dunia nyata siswa/ koneksi dengan kehidupan sehari-hari. Kemampuan koneksi penting dimiliki oleh siswa agar mereka mampu menghubungkan antara materi yang satu dengan materi yang lainnya. Selain itu, jika siswa mampu mengaitkan materi yang mereka pelajari dengan pokok bahasan sebelumnya atau dengan mata pelajaran lain, maka pembelajaran matematika menjadi lebih bermakna.

Kemampuan koneksi matematis merupakan salah satu kemampuan berpikir tingkat tinggi yang sangat penting dan harus dikembangkan karena dalam pembelajaran matematika setiap konsep berkaitan satu sama lain dengan konsep lainnya. Bruner (2009) menyatakan bahwa anak perlu menyadari bagaimana hubungan antar konsep, karena antara sebuah bahasan dengan bahasan matematika lainnya saling berkaitan. Lasmawati (Lestari, 2014) mengungkapkan bahwa melalui koneksi matematis, wawasan siswa akan semakin terbuka terhadap matematika, yang kemudian akan menimbulkan sikap positif 
terhadap matematika itu sendiri. Melalui proses koneksi matematis, konsep pemikiran dan wawasan siswa terhadap matematika akan semakin lebih luas, tidak hanya terfokus pada topik yang sedang dipelajari. Berdasarkan pengertian di atas maka dapat disimpulkan bahwa kemampuan koneksi matematis adalah kemampuan dalam mengaitkan konsep-konsep matematika baik antar konsep matematika itu sendiri maupun mengaitkan konsep matematika dengan bidang lain serta mengaitkan dalam kehidupan sehari-hari.

Menurut NCTM (2000) koneksi matematika merupakan bagian penting yang harus mendapat penekanan di setiap jenjang pendidikan. Koneksi matematika adalah keterkaitan antar topik matematika, keterkaitan antar matematika dengan disiplin ilmu lain, dan keterkaitan matematika dengan dunia nyata atau dalam kehidupan sehari-hari. Kemampuan koneksi matematika merupakan salah satu faktor penting dalam melakukan pemahaman konsep matematika. Dengan melakukan koneksi, konsep-konsep matematika yang telah dipelajari tidak ditinggalkan begitu saja sebagai bagian yang terpisah, tetapi digunakan sebagai pengetahuan dasar untuk memahami konsep yang baru. Siswa menunjukkan kemampuan koneksi matematika ketika mereka memberikan bukti bahwa mereka dapat memenuhi indikator koneksi matematis menurut NCTM (2000) yaitu:

1. Mengenali dan menggunakan hubungan antar ide-ide dalam matematika.

Dalam hal ini, koneksi dapat membantu siswa untuk memanfaatkan konsep-konsep yang telah mereka pelajari dengan konteks baru yang akan dipelajari oleh siswa dengan cara menghubungkan satu konsep dengan konsep lainnya.
2. Memahami keterkaitan ide-ide matematika dan membentuk ide satu dengan yang lain sehingga menghasilkan suatu keterkaitan yang menyeluruh. Memahami bagaimana gagasan-gagasan dalam matematika saling berhubungan dan mendasari satu sama lain untuk menghasilkan suatu keutuhan koheren.

3. Mengenali dan mengaplikasikan matematika ke dalam kehidupan sehari-hari. Konteks-konteks eksternal matematika pada tahap ini berkaitan dengan hubungan matematika dengan kehidupan sehari-hari, sehingga siswa mampu mengkoneksikan antara kejadian yang ada pada kehidupan sehari-hari (dunia nyata) ke dalam model matematika.

Adapun penilaian kemampuan koneksi matematis didasarkan pada pedoman penskoran kemampuan koneksi matematis yang dimodifikasi dari Sumarmo (Ramdhani, 2012) sebagai berikut:

Tabel 1. Pedoman Penskoran Tes Kemampuan Koneksi Matematis

\begin{tabular}{|c|c|}
\hline $\begin{array}{c}\text { Reaksi Terhadap Soal/ } \\
\text { Masalah }\end{array}$ & Skor \\
\hline $\begin{array}{l}\text { Tidak ada jawaban/ } \\
\text { koneksinya tidak jelas }\end{array}$ & 0 \\
\hline $\begin{array}{l}\text { Jawaban hanya sedikit yang } \\
\text { benar/ sesuai dengan } \\
\text { pertanyaan, persoalan atau } \\
\text { dengan masalah }\end{array}$ & 1 \\
\hline $\begin{array}{l}\text { Jawaban hampir semua } \\
\text { benar/ sesuai dengan } \\
\text { pertanyaan, persoalan atau } \\
\text { dengan masalah, tetapi } \\
\text { memuat sedikit kesalahan }\end{array}$ & 2 \\
\hline Semua benar & 3 \\
\hline
\end{tabular}

Sehubungan dengan pentingnya kemampuan koneksi matematis, maka diperlukan penelitian mengenai 
kemampuan koneksi matematis siswa. Tujuan penelitian ini adalah untuk mengetahui dan mendeskripsikan profil kemampuan kemampuan koneksi matematis siswa SMPN 1 dan SMPN 2 Kepenuhan Melalui kajian ini akan diperoleh informasi penting bagi peneliti maupun guru di sekolah yang akan digunakan sebagai bahan evaluasi atau sebagai penentu langkah berikutnya untuk melakukan tindak lanjut, baik berupa perbaikan proses pembelajaran maupun berupa penelitian yang lebih kompleks.

\section{METODE PENELITIAN}

Jenis penelitian ini merupakan penelitian deskriptif kuantitatif. Menurut Sugiyono (2011: 13) metode kuantitatif adalah penelitian berupa angka-angka dan analisis menggunakan statistik. Sedangkan penelitian deskriptif menurut Sugiyono (2011: 13) adalah penelitian yang dilakukan untuk mengetahui nilai variable mandiri, baik satu variable atau lebih (independen) tanpa membuat perbandingan, atau menghubungkan dengan variabel yang lain. Berdasarkan teori tersebut, penelitian deskriptif kuantitatif, merupakan data yang diperoleh dari sample populasi penelitian dianalisis sesuai dengan metode statistic yang digunakan. Penelitian deskriptif dalam penelitian ini dimaksudkan untuk mendapatkan gambaran dan keteranganketerangan mengenai kemampuan koneksi matematis siswa SMPN 1 dan SMPN 2 Kepenuhan.

Pelaksanaan penelitian mengikuti tahap-tahap: (1) merumuskan indikatorindikator kemampuan koneksi matematis, (2) merumuskan instrument tes yang valid dan reliabel, (3) melakukan pengambilan data untuk mengetahui profil kemampuan koneksi siswa, (4) melakukan analisis data (6) melakukan pembahasan hasil analisis data, (7) melakukan penarikan kesimpulan, dan (8) menyusun laporan akhir.

Populasi pada penelitian ini adalah seluruh siswa SMPN 1 dan SMPN 2 Kepenuhan. Teknik pengambilan sampel menggunakan teknik purposive sampling dengan asumsi bahwa kemampuan koneksi matematis yang dimiliki siswa pada sekolah tersebut relatif sama. Sampel penelitian ini adalah siswa yang berasal dari dua kelas yang diambil dari masing-masing satu kelas VIII pada SMPN 1 dan SMPN 2 Kepenuhan.

Teknik pengumpulan data yang digunakan adalah teknik tes. Teknik tes dilakukan untuk memperoleh data kemampuan koneksi matematis siswa. Data kemampuan koneksi matematis siswa diperoleh dari lembar jawaban yang dikerjakan siswa. Data kemampuan koneksi matematis siswa yang diperoleh selanjutnya dinilai menggunakan rubrik penskoran kemampuan koneksi matematis yang telah ditetapkan untuk mengetahui profil kemampuan koneksi matematis siswa. Metode analisis yang digunakan pada penelitian ini adalah deskriptif persentase yang dilakukan menggunakan program Microsoft Excel. Selanjutnya hasil analisis tersebut dideskripsikan berdasarkan perolehan data pada jawaban soal tes kemampuan koneksi matematis siswa yang disajikan melalui tabel dan grafik.

\section{HASIL PENELITIAN DAN PEMBAHASAN}

Tes kemampuan koneksi matematis diberikan kepada dua kelas siswa kelas VIII. Satu kelas dari SMPN 1 Kepenuhan sebanyak 17 siswa dan satu kelas lagi dari SMPN 2 Kepenuhan sebanyak 24 siswa. Data hasil tes disajikan pada Tabel 2 berikut. Data yang disajikan merupakan skor tes kemampuan koneksi matematis yang telah dikonversi dengan rentang 0100. 
Tabel 2. Deskripsi Data Kemampuan Koneksi Matematis Siswa

\begin{tabular}{|c|l|r|r|r|r|}
\hline $\begin{array}{c}\text { Indi- } \\
\text { kator }\end{array}$ & Sekolah & $\bar{x}$ & $S$ & $x_{\max }$ & $x_{\min }$ \\
\hline \multirow{2}{*}{1} & SMPN 1 & 54,90 & 20,21 & 66,67 & 0,00 \\
\cline { 2 - 6 } & SMPN 2 & 0,00 & 0,00 & 0,00 & 0,00 \\
\hline \multirow{2}{*}{2} & SMPN 1 & 66,67 & 0,00 & 66,67 & 66,67 \\
\cline { 2 - 6 } & SMPN 2 & 8,33 & 17,72 & 66,67 & 0,00 \\
\hline \multirow{2}{*}{3} & SMPN 1 & 0,00 & 0,00 & 0,00 & 0,00 \\
\cline { 2 - 6 } & SMPN 2 & 13,89 & 16,79 & 33,33 & 0,00 \\
\hline \multirow{2}{*}{ Total } & SMPN 1 & 40,52 & 6,74 & 44,44 & 22,22 \\
\cline { 2 - 6 } & SMPN 2 & 7.41 & 7,08 & 22,22 & 0,00 \\
\hline
\end{tabular}

Keterangan Indikator:

1. Koneksi antar konsep matematika

2. Koneksi antara matematika dan bidang studi lain

3. Koneksi antara matematika dan kehidupan sehari-hari

$\bar{x} \quad$ : Rata-Rata

$\mathrm{S}$ : Simpangan Baku

$x_{\max }$ : Nilai Tertinggi

$x_{\min }$ : Nilai Terendah

Berdasarkan data pada Tabel 2 dapat diketahui bahwa nilai kemampuan koneksi matematis siswa SMPN 1 dan SMPN 2 Kepenuhan masih sangat rendah. SMPN 2 Kepenuhan bahkan memperoleh skor rata-rata dibawah $10 \%$. Nilai tertinggi yang diperoleh siswa hanya 44,44 . Hal ini menunjukkan bahwa siswa paling pandai di kelas tersebut bahkan tidak memperoleh nilai yang membanggakan. Nilai terendah diperoleh oleh siswa dari SMPN 2 Kepenuhan, yaitu nilai 0 . Hal ini menunjukkan bahwa terdapat siswa yang tidak dapat menjawab satupun soal kemampuan koneksi matematis.

Jika dilihat dari rata-rata setiap indikator kemampuan koneksi matematis, indikator dengan perolehan nilai terendah yaitu indikator ketiga yang meminta siswa melakukan koneksi antara matematika dan kehidupan sehari-hari. Rata-rata nilai indikator ketiga dari kedua sekolah adalah 6,95. Indikator dengan perolehan nilai tertinggi yaitu indikator kedua yang meminta siswa melakukan koneksi antara matematika dengan bidang studi lain. Rata-rata nilai indikator kedua dari kedua sekolah adalah 37,5.

Grafik 1 berikut menyajikan ratarata nilai setiap indikator kemampuan koneksi matematis siswa. Grafik 1 memperlihatkan bahwa pada indikator 1 dan indikator 2, siswa SMPN 1 lebih unggul dibandingkan siswa SMPN 2. Namun pada indikator 3, siswa SMPN 2 lebih unggul dibandingkan siswa SMPN 1.

Rata-rata Nilai Setiap Indikator

Kemampuan Koneksi Matematis Siswa

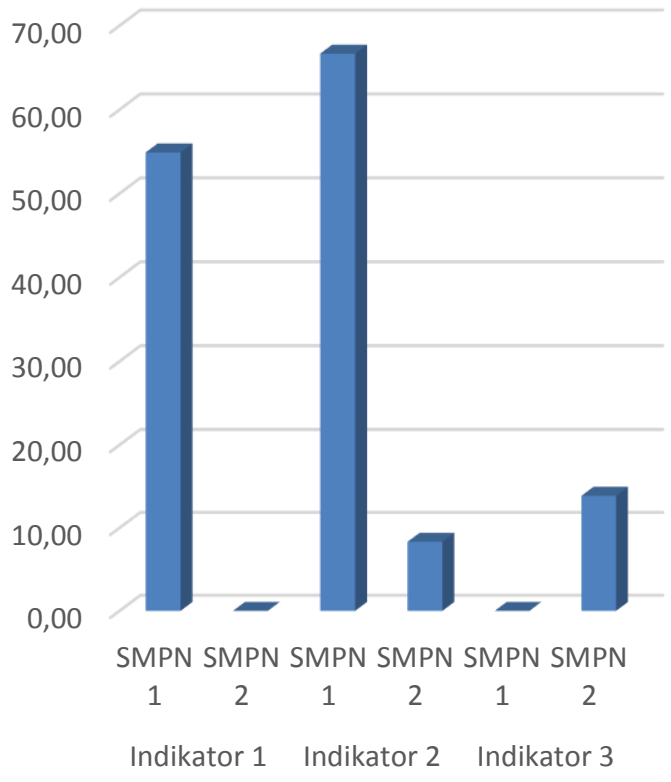

Grafik 1. Rata-rata Nilai Setiap Indikator Kemampuan Koneksi Matematis Siswa

Data pada Tabel 4 dan Grafik 1 memperlihatkan suatu fakta yang unik. Siswa SMPN 1 memperoleh nilai rata-rata 54.90 pada Indikator 1 sedangkan siswa SMPN 2 memperoleh nilai rata-rata 0 . Artinya, tidak ada satupun siswa SMPN 2 yang mampu menjawab Indikator 1 . Namun, hal sebaliknya terjadi pada Indikator 3. Siswa SMPN 2 memperoleh rata-rata 13.89 sedangkan siswa SMPN 1 memperoleh rata-rata 0 . Artinya tidak ada satupun siswa SMPN 1 yang mampu menjawab soal Indikator 3. Dengan demikian dapat disimpulkan bahwa siswa di SMPN 1 mengalami kesulitan dalam 
menyelesaikan soal-soal kemampuan koneksi matematis yang berhubungan dengan kehidupan sehari-hari. Sedangkan siswa di SMPN 2 mengalami kesulitan dalam menyelesaikan soal-soal kemampuan koneksi matematis yang melibatkan beberapa konsep dalam matematika.

Secara keseluruhan dapat diketahui bahwa tidak ada satupun siswa dari kedua sekolah yang mampu memperoleh nilai yang baik. Jika dilihat dari setiap indikator kemampuan koneksi matematis, tidak ada satu siswa pun dari kedua sekolah yang mampu menjawab satu soal secara sempurna. Hasil ini menunjukkan bahwa kemapuan koneksi matematis siswa SMPN 1 dan SMPN 2 masih sangat rendah.

Rendahnya kemampuan koneksi matematis siswa di kedua sekolah tersebut bisa disebabkan oleh beberapa hal. Perlu suatu pengkajian yang lebih dalam untuk melihat penyebab tersebut. Tindakan lebih lanjut untuk mengatasi penyebab rendahnya kemampuan koneksi matematis juga diperlukan untuk perbaikan kualitas pendidikan di kedua sekolah.

\section{SIMPULAN}

Kesimpulan yang diperoleh dari hasil penelitian ini adalah sebagai berikut:

1. Kemampuan koneksi matematis SMPN 1 dan SMPN 2 Kepenuhan masih sangat rendah. Rata-rata kemampuan koneksi masing-masing sekolah adalah 40.52 dan 7.41 .

2. Indikator kemampuan koneksi matematis yang paling sulit bagi siswa SMPN 1 Kepenuhan adalah menghubungkan antara matematika dan kehidupan sehari-hari.

3. Indikator kemampuan koneksi matematis yang paling sulit bagi siswa SMPN 2 Kepenuhan adalah menghubungkan berbagai konsep dalam matematika.
Berdasarkan hasil penelitian dan kesimpulan yang diperoleh, diajukan beberapa saran sebagai berikut:

1. Perlu kajian mendalam tentang penyebab rendahnya kemampuan koneksi matematis siswa SMPN 1 dan SMPN 2 Kepenuhan.

2. Perlu usaha serius untuk memperbaiki kemampuan koneksi matematis siswa SMPN 1 dan SMPN 2 Kepenuhan.

\section{UCAPAN TERIMAKASIH}

Terimakasih kami ucapkan kepada Pemerintah Daerah Rokan Hulu yang telah memberikan hibah, sehingga penelitian ini dapat dilaksanakan dengan maksimal.

\section{DAFTAR PUSTAKA}

Bruner, JS. (2009). Discovery Learning Model as the Theoretical Basis of Light Bounces Lesson. Journal EDT665 Fall December 2009.

Depdiknas. (2006). Standar Isi untuk Satuan Pendidikan Dasar dan Menengah. Jakarta: BSNP.

Lestari, KE. (2014). Implementasi BrainBased Learning Untuk Meningkatkan Kemampuan Koneksi Dan Kemampuan Berpikir Kritis Serta Motivasi Belajar Siswa Smp. Jurnal Pendidikan UNSIKA Vol 2, No 1, November 2014.

National Council of Teachers of Mathematics. 2000. Principles and Standards for School Mathematics. United State: Nasional Council of Teachers of Mathematics, Inc.

Ramdhani, S. (2012). Pembelajaran Matematika dengan Pendekatan Problem Posing Untuk Meningkatkan Kemampuan Pemecahan Masalah dan Koneksi Matematis Siswa. Jurnal Kependidikan Universitas 


\section{Pendidikan Indonesia.}

Repository.upi.edu

Sugiman. (2008). Koneksi Matematika Dalam Pembelajaran Matematika di Sekolah Menengah Pertama. Vol 4, No 1. Juni 2008.

Sugiyono. (2011). Metode Penelitian Pendidikan Pendekatan Kuantitatif, Kualitatif, dan $R \& D$. Bandung: Alfabeta. 